12 Charlesworth M. A good death. In: Kuhse $\mathrm{H}$, ed. Willing to listen - waiting to die. Melbourne: Penguin, 1994: 203-16.

13 Marker R. Deadly compassion. The death of Ann Humphry and the case against euthanasia. London:
Harper Collins, 1994.

14 Humphry D. Dying with dignity: understanding euthanasia. New York: Birch Lane Press, 1992.

15 Kennedy L. Euthanasia. London: Chatto \& Windus, 1990.

News and notes

\title{
UK's Muslim Law Council approves organ transplants
}

The council, which consists of scholars from all the major Muslim schools of law in the UK, together with three distinguished lawyers, has considered the issue of organ transplantation and has made a statement that reflects the council's resolutions. The statement has been agreed by Sunni as well as Shia scholars. It is signed by M A Zaki Badawi, Chairman of The Muslim Law (Shariah) Council.

It is important to note the following principles of Islamic jurisprudence. The council points out:

1. A person has the legal authority over his own body, attested by the fact that he can hire himself for work which might be difficult or exhausting. He may also volunteer for war which may expose him to death.

2. A person is forbidden from harming himself or others. (It is not legitimate in Islam to inflict harm on others or to suffer harm from them - Haddith).

3. In case of necessity, certain prohibitions are waived, as when the life of a person is threatened by the prohibition on eating carrion or drinking wine.

4. Confronted with two evils a person is permitted to choose the lesser of the two, as in the case of a starving person whose life could be saved by either eating carrion or stealing from another person's food. He would be permitted to opt for the latter.

5. Islam made it an obligation upon the sick to seek treatment.
In the light of these principles, and after thorough consideration "regarding medical opinion and several edicts issued by different religious bodies", the council has resolved that:

- The medical profession is the proper authority to define the signs of death.

- Current medical knowledge considers brain stem death to be a proper definition of death.

- The council accepts brain stem death as constituting the end of life for the purpose of organ transplant.

- The council supports organ transplant as a means of alleviating pain or saving life on the basis of the rules of Shariah.

- Muslims may carry donor cards.

- The next of kin of a dead person, in the absence of a donor card or an expressed wish of the dead person to donate his organs, may give permission to obtain organs from the body to save other people's lives.

- Organ donation must be given freely without reward. Trading in organs is prohibited.

More information may be obtained from: The Muslim Law (Shariah) Council, 20-22 Creffield Road, London, W5 3RP. Tel: +44-81-992-6636 - Fax: +44-81-993-3946. 